\title{
Prototype Arc Saw Design and Cutting Trials
}

\author{
G. S. Allison
}

September 1980

Prepared for the U.S. Department of Energy under Contract DE-AC06-76RLO 1830

Pacific Northwest Laboratory Operated for the U.S. Department of Energy by Battelle Memorial Institute 


\title{
NOTICE
}

This report was prepared as an account of work sponsored by the United States Government. Neither the United States nor the Department of Energy, nor any of their employees, nor any of their contractors, subcontractors, or their employees, makes any warranty, express or implied, or assumes any legal liability or responsibility for the accuracy, completeness or usefulness of any information, apparatus, product or process disclosed, or represents that its use would not infringe privately owned rights.

The views, opinions and conclusions contained in this report are those of the contractor and do not necessarily represent those of the United States Government or the United States Department of Energy.

\author{
PACIFIC NORTHWEST LABORATORY \\ operated by \\ BATTELLE \\ for the \\ UNITED STATES DEPARTMENT OF ENERGY \\ Under Contract DE-AC06-76RLO 1830
}

\author{
Printed in the United States of America \\ Available from \\ National Technical Information Service \\ United States Department of Commerce \\ 5285 Port Royal Road \\ Springfield, Virginia 22151
}

Price: Printed Copy S $\because$ Microfiche $\$ 3.00$

NTIS

-Pages Selling Price

\begin{tabular}{|c|c|}
\hline $001-025$ & $\$ 4.00$ \\
\hline $026-050$ & $\$ 4.50$ \\
\hline $051-075$ & $\$ 5.25$ \\
\hline $076-100$ & $\$ 6.00$ \\
\hline $101-125$ & $\$ 6.50$ \\
\hline $126-150$ & $\$ 7.25$ \\
\hline $151-175$ & $\$ 8.00$ \\
\hline $176-200$ & $\$ 9.00$ \\
\hline $201-225$ & $\$ 9.25$ \\
\hline $226-250$ & $\$ 9.50$ \\
\hline $251-275$ & $\$ 10.75$ \\
\hline $276-300$ & 511.00 \\
\hline
\end{tabular}




\section{1}

PROTOTYPE ARC SAW DESIGN AND CUTTING TRIALS

G. S. Allison

September 1980

Prepared for the U.S. Department of Energy under Contract DE-AC06-76RL0 1830

Pacific Northwest Laboratory Richland, Washington 99352 
,

'

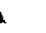




\section{SUMMARY}

The Fuel Cycle Program Office of the Department of Energy initiated a program at the Pacific Northwest Laboratory to develop the arc saw as a tool capable of removing the end fittings from spent nuclear fuel bundles. A special arc saw for this purpose was designed, installed at the Pacific Northwest Laboratory and satisfactorily operated to remove end fittings from simulated, nonradioactive fuel bundles.

The design of the arc saw included consideration of the cutting environment, power supply size, control equipment, and work piece size. Several simulated fuel bundles were cut to demonstrate that the arc saw met design specifications. Although the arc saw development program was curtailed before significant performance data could be collected, tests indicate that the arc saw is a good means of cropping spent fuel bundles and is well suited to remote operation and maintenance. It is recommended that completion of the arc saw development program be directed toward optimizing arc saw cutting parameters, work piece positioning equipment, and detritus collection and handling methods. 


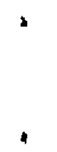




\section{CONTENTS}

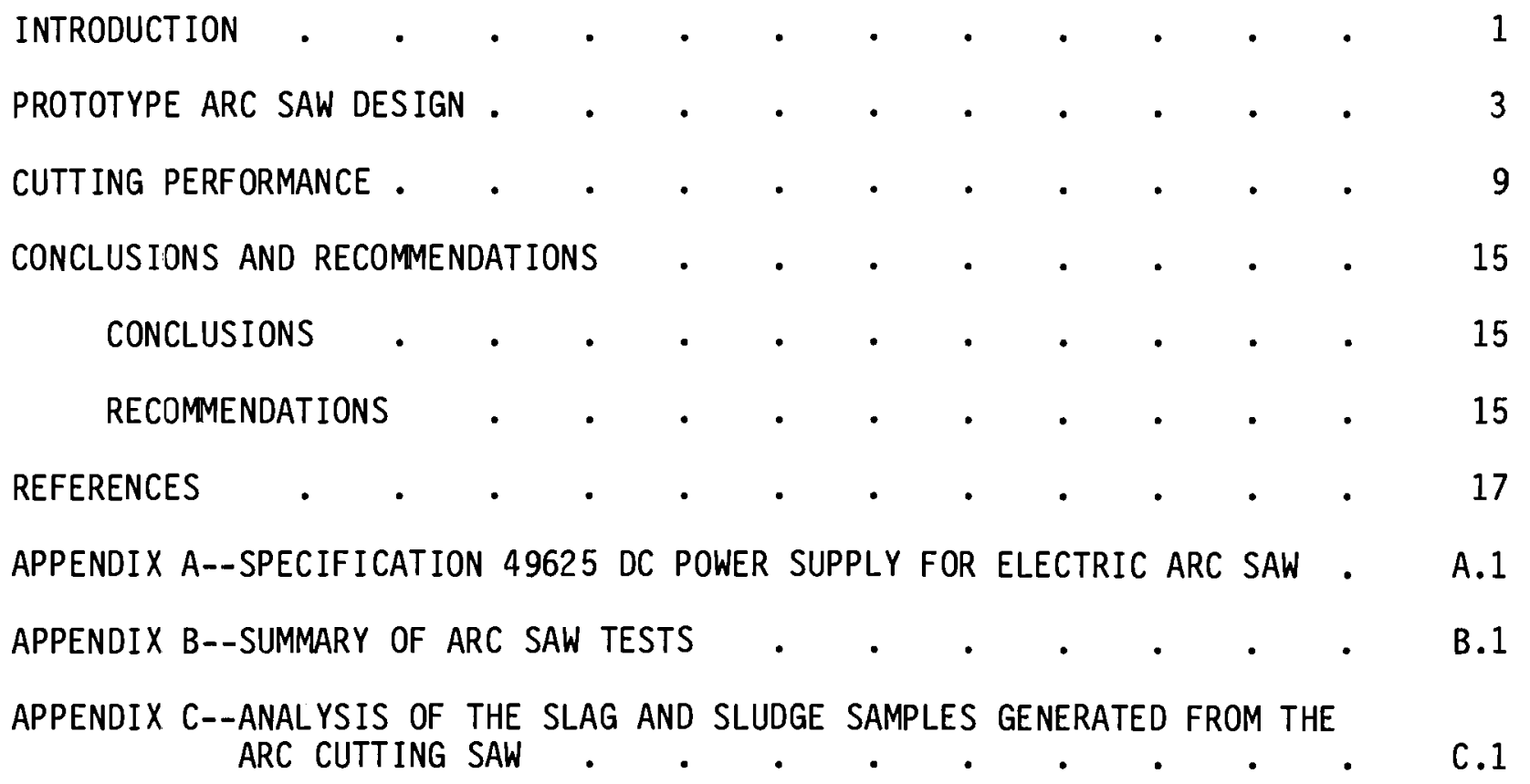




\section{FIGURES}

1 Schematic View of PNL Arc Saw . $\quad$ • . . . . . . . $\quad 5$

2 Front View of PNL Arc Saw During Installation . . . . 6

3 View into Tank of PNL Arc Saw Showing Saw and Traveling Bridge . 7

4 Simulated BWR Fuel Bundles with Springs Shown as Cut on the PNL Arc

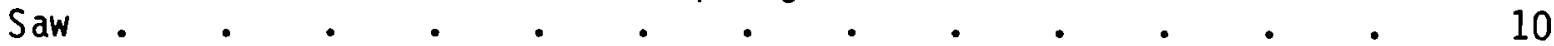

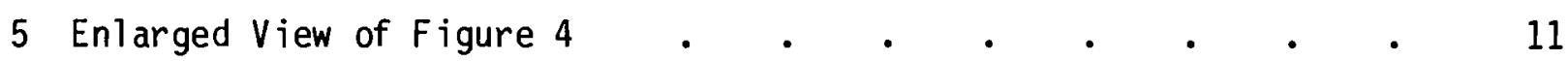

6 Detritus from Cutting Zircaloy with an Arc Saw at 2000 A $\quad$ • 12

7 Detritus from Cutting Zircaloy with an Arc Saw at 2000 A . . 13

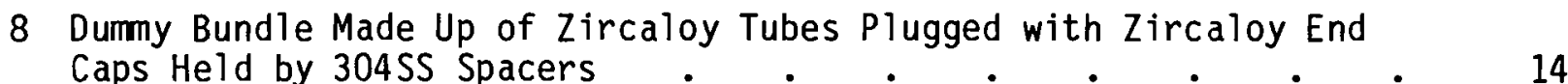

A.1 Arc Saw Power Supply Voltage-Current Characteristics - • - A.3 
PROTOTYPE ARC SAW DESIGN AND CUTTING TRIALS

INTRODUCTION

The electric arc saw was initially considered in late 1976 for incorporation into the head end of a conceptual light water reactor (LWR) fuel reprocessing plant where the saw would remove the end fittings from spent nuclear fuel bundles. The original concept was to utilize the arc saw to cut off the end fittings to facilitate disassembly of the fuel bundle into fuel rods which would continue through the reprocessing cycle. This disassembly concept was introduced late enough in the overall program that the technology could not have been proven in time to be included in the final plant conceptual design. However, the removal of the end fittings prior to chopping the fuel bundle appeared both feasible and attractive from the standpoint of removing large chunks of hardware from the processing stream and subsequent transuranic (TRU) waste storage. Consequently, the program to develop the arc saw for this purpose was initiated at the Pacific Northwest Laboratory (PNL) by the Fuel Cycle Program Office at Savannah River.

The arc saw is a proprietary device conceived and developed by RETECH, Inc. of Ukiah, California. It comprises basically a rotating, toothless metal blade, a direct current power supply, and controls which feed the blade into the workpiece. The cutting action is derived from the direct current arc between the blade and the metal workpiece. This arc melts the portion of the work in the saw kerf, which is expelled by the rotation of the blade. Several features of the arc saw that made it very attractive for remote operation in a radioactive work area are:

- no physical contact between the saw and the work (no pressure on the work)

- easily adapted to remote maintenance

- excellent positioning control for operation inside a hot cell 
- only saw head and drive inside the hot cell; power supplies and electronic controls outside

- rapid cutting action--high throughput.

The arc saw end fitting removal program was originated with the objectives of 1) designing and procuring a prototype arc saw for the removal of fuel bundle end fittings, 2) installing and operating the saw to develop the parameters required for installation and operation in a processing plant, and 3 ) providing design information input to the conceptual processing plant design. Overall fuel cycle programmatic changes required reduction of effort to the point that objectives 2 and 3 were curtailed. The saw was designed, installed at the Pacific Northwest Laboratory, and satisfactorily operated to remove end fittings from dummy (simulated, nonradioactive) fuel bundles.

This report describes the prototype arc saw design and the results of cutting trials, including the cutting trials performed on the manufacturer's original demonstration model. 


\section{PROTOTYPE ARC SAW DESIGN}

The purpose of this arc saw was to serve as the prototype of a spent fuel end fitting removal (cropping) facility for a conceptual LWR fuel reprocessing plant. The cropping facility would have been included in the mechanical processing cell at the head end of the process. It was decided that the fuel bundle would be delivered to the saw underwater in the horizontal position in a water tank. The saw would be designed to accept the bundle in the horizontal position, clamp it, and connect it electrically to the arc circuit ground. The saw blade would be positionable at each end of the bundle for cropping.

Preliminary cutting of short, dummy bundles on the manufacturer's (RETECH) arc saw indicated that a 3000-A dc arc power supply would be large enough to crop fuel bundles. The following functional specification for the prototype arc saw was based on this demonstrated power requirement and the functional requirement of the ultimate conceptual processing facility.

The arc saw system shall comprise:

1. the 3000-A direct current arc power supply (The detailed specification for this power supply is included in Appendix A.)

2. the arc saw proper

3. the arc saw controls

4. the hydraulic power supply for the saw drive and feed.

The arc saw proper shall meet the following functonal requirements: the $\operatorname{arc}$ saw

1. shall handle minimum arc current of $3000-A \mathrm{dc}$

2. shall have hydraulic drive and feed

3. shall be capable of cutting in both the down vertical and back-tofront horizontal directions at the maximum rate compatible with the arc power supply

4. shall be capable of cutting completely a cross section of 10-in. x 10-in., minimum 
5. shall be hand positionable (with provisions for modifying the saw to be remotely positionable) at any cutting plane along the $15-\mathrm{ft}$ axis of the fuel bundle

6. shall have a maximum kerf of 0.2 in.

7. shall be equipped with a mild steel water tank capable of containing and fixturing a 10-in. $\times 10-i n . \times 15-f t$ bundle underwater in the proper position for cutting.

In addition:

8. The water tank shall be equipped with an air drive water handling system to rapidly fill and empty the tank.

9. The saw controls, dc power supply, and hydraulic power supply shall be contained in separate cubicles remote from the saw.

The arc saw procured to meet these specificatons is shown schematically in Figure 1. The saw tank is mounted on two interconnected, cylindrical water storage tanks. The water is transferred through the water transfer pipes to the saw tank by pressurizing the storage tanks with low-pressure air. The saw tank is emptied by venting the storage tanks to atmosphere and thus draining the water back into them. This feature facilitates experimental cutting by rapidly filling and emptying the saw tank. The tank-storage tank arrangement is very rigid and provides an accurate, firm base on which the saw operates.

The saw head contains the blade-rotating, hydraulic motor drive as well as the slip-rings and insulation necessary to conduct the arc current to the blade. The saw head is mounted on a vertical hydraulic cylinder which in turn is mounted on a horizontal hydraulic cylinder. The vertical cylinder and the horizontal cylinder provide, through electro-hydraulic servo valves, the vertical and horizontal cutting feeds, respectively. The saw is capable of cutting strokes 12 in. down and 24 in. back-to-front.

The longitudinal positioning of the saw is accomplished from the control console by a reversible electric motor that drives pinions against racks under the longitudinal ways. This drive is presently on/off controlled, but can be readily converted to servo-control for accurate, remote positioning as would 
PNL ARC SAW

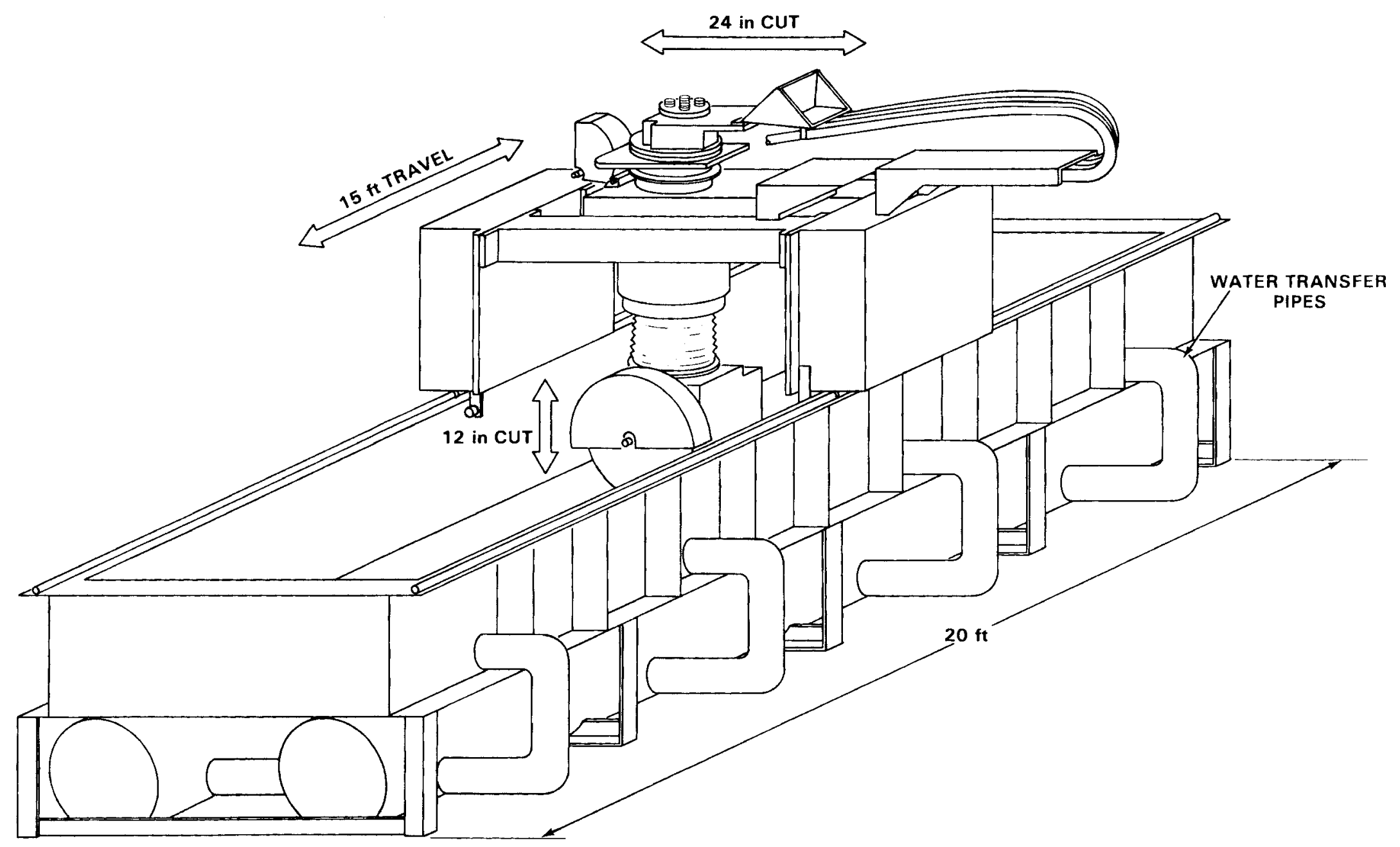

FIGURE 1. Schematic View of PNL Arc Saw (The saw blade is 30 in. in diameter and rotates at $1000 \mathrm{rpm}$. The dc power supply has 3000-A capacity.) 
be required in a remote, cell operation. Also, with a servo on the longitudinal drive the saw head can be rotated $90^{\circ}$ so that longitudinal cuts of $15-\mathrm{ft}$ lengths can be performed. This increases the versatility of the saw for development of techniques such as fuel bundle disassembly by cutting spacer grids between fuel rods.

The saw blade, which is nominally $30 \mathrm{in}$. in diameter, rotates at about $1000 \mathrm{rpm}$. This pumps a lot of water around the blade which can be utilized in the future to collect the cutting debris by circulating it through filters. . The only penetration of the cell wall in a remote operaton would be 1) hydraulic lines for the blade drive and the feed, and 2) electric lines for the positioning and control functions.

Figures 2 and 3 are views of the PNL arc saw during installation. The horizontal position of the fuel bundle during cutting was selected because:

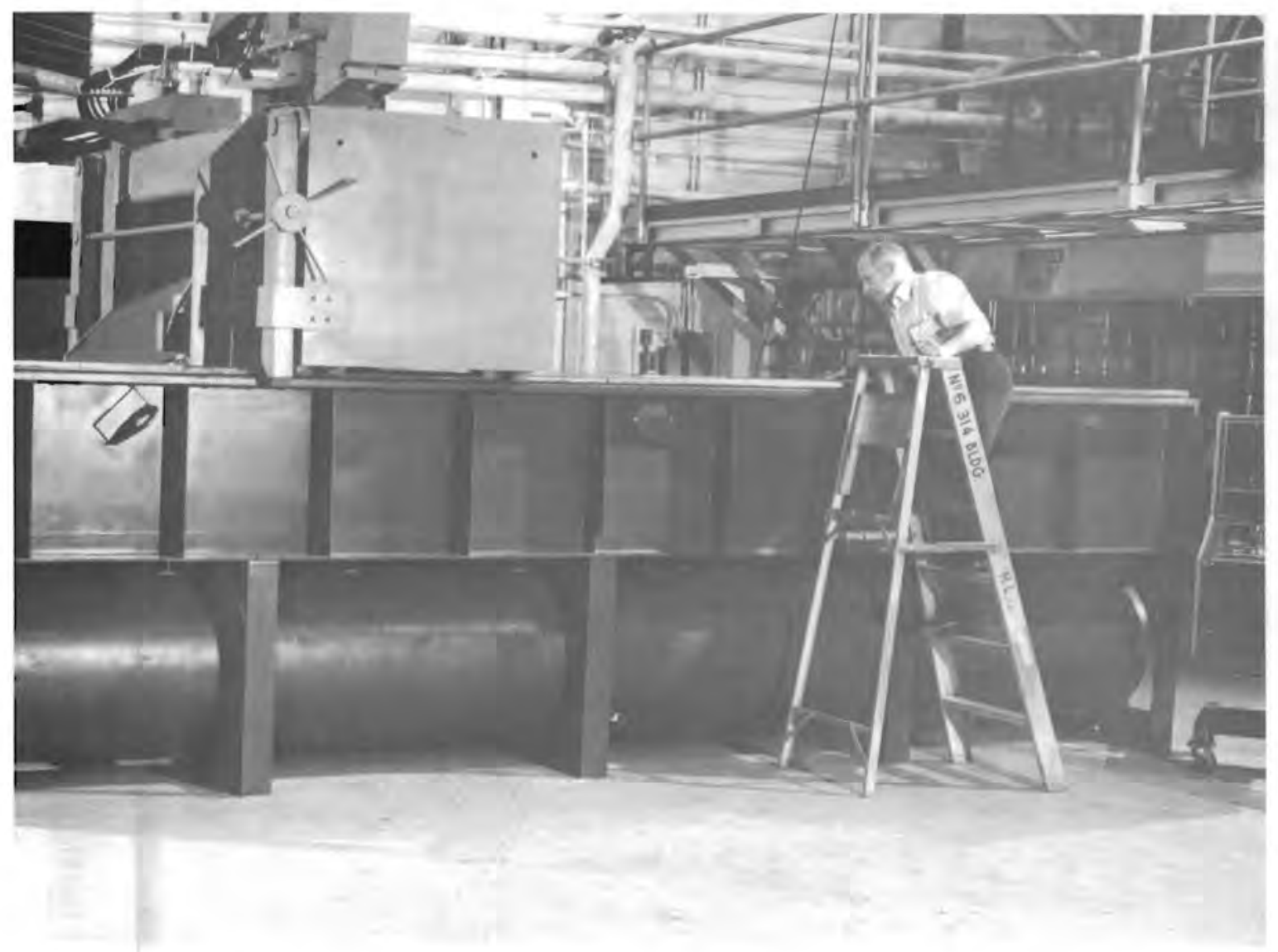

FIGURE 2. Front View of PNL Arc Saw During Installation 


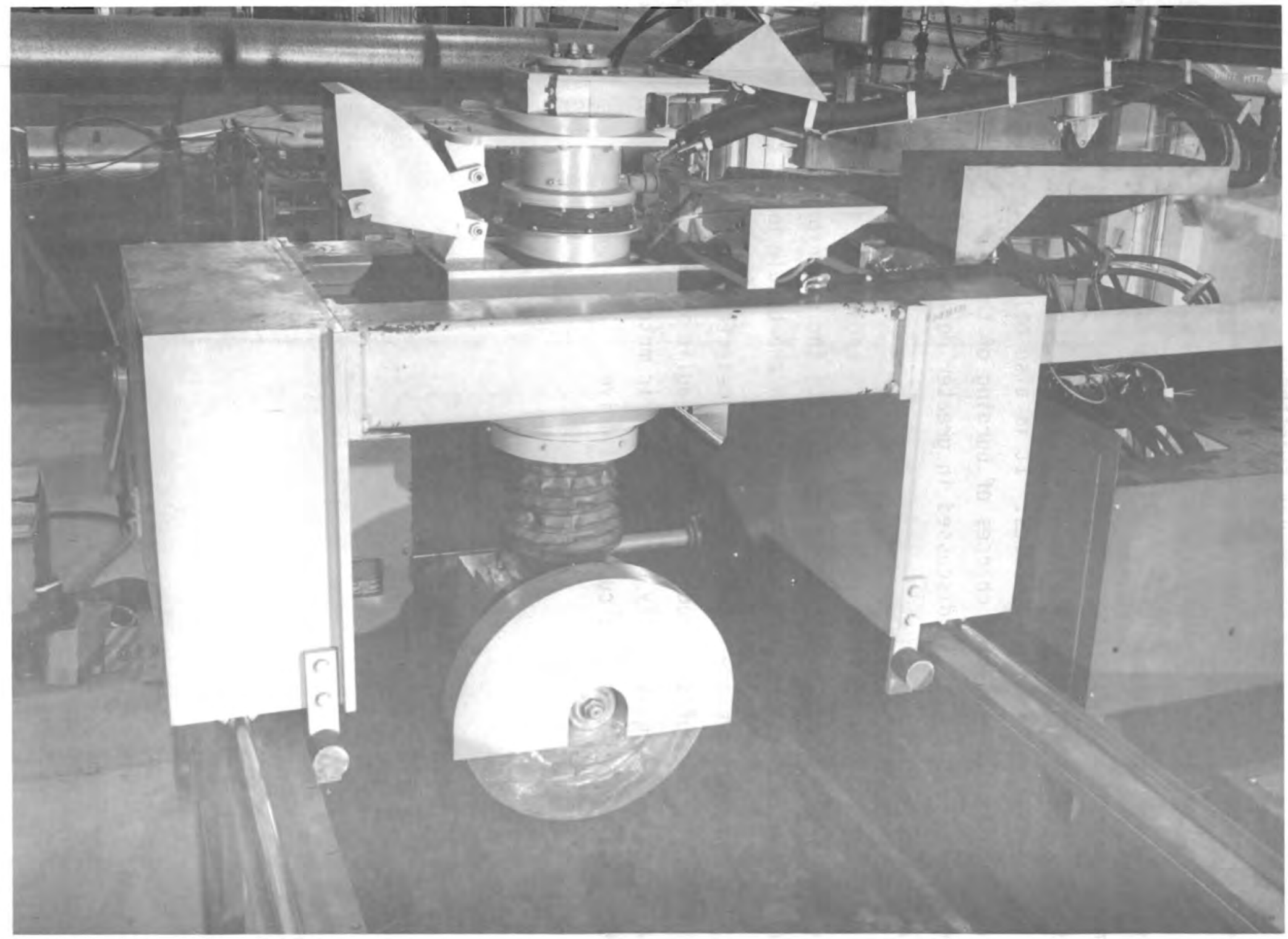

FIGURE 3. View into Tank of PNL Arc Saw Showing Saw and Traveling Bridge 
- It provided a simpler saw design than the vertical mode.

- The fuel bundle had to be in the horizontal position for the next operation in the conceptual process (chopping in a shear).

Cutting under water was selected because it enhanced the bundle cooling, the control of radioactive crud on the fuel bundle, and the ability to collect the detritus from the cutting action. Tests showed the cutting detritus to be heavily oxidized zirconium globules. It is also believed that cutting under water greatly minimizes the chances of burning of the zirconium fines that are generated. This aspect is discussed in greater detal under "Cutting Performance."

The ability to position the blade at each end of the fuel bundle was designed into the prototype saw to demonstrate the superiority of this mode over one which utilized a fixture to position the bundle under the saw.

The hydraulic blade-rotating drive was selected over the electric drive primarily because of size reduction. A hydraulic motor in the saw head is much smaller than the equivalently powered electric motor. Then, too, the hydraulic system was required for the cutting feed drive. 


\section{CUTTING PERFORMANCE}

Prior to procurement of this arc saw, several cutting trials were performed with the manufacturer's arc saw using stand-in dummy bundles. Their purpose was to establish a basis for designing this arc saw and to determine the general framework of parameters within which the development could be carried out. A topical report (Weihermiller 1978) was issued for part of this work and it is covered briefly here as background.

The program for this arc saw was curtailed before any significant fuel bundle cropping data could be collected. There were, however, enough cuts made on dummy fuel bundles to demonstrate that the saw met the manufacturer's performance claims and that the PNL saw is an excellent tool for continuing the fuel bundle cropping development. One of these cuts is shown in Figures 4 and 5 . The simulated bundle was made up of Zircaloy rods with turned down ends over which were placed Inconel springs, which were placed as shown in $8 \times 8$ rod grids. The cut was made at about 2000-A arc current in ten seconds. The purpose of this cut was to demonstrate the saw's ability to cut through loosely connected pieces of different materials.

There has not been sufficient cutting or cropping of simulated fuel bundles to determine wear rates for the arc saw blades in this service. It appears that, based on this and other types of cutting, the wear of the blade will be moderate to minimal and thus afford a long and economical life between changes as compared, for instance, to abrasive cut-off wheels.

One of the primary concerns in using an arc saw to cut zirconium is the safety of handling the detritus, or swarf, from the cut. The characterizaton of this detritus with varying arc saw cutting parameters was to have been one of the main objectives of the program. Since the program was curtailed, the data from the cutting trials on the manufacturer's saw are discussed to afford the reader a brief introduction to the general character of the detritus.

The detritus comprises variable sizes and globular particles of heavily oxidized zirconium metal. Figures 6 and 7 show the detritus collected from the arc saw cropping of the dummy zircaloy fuel bundle shown in Figure 8 . The detritus was collected from several cuts made under water on the manufacturer's 


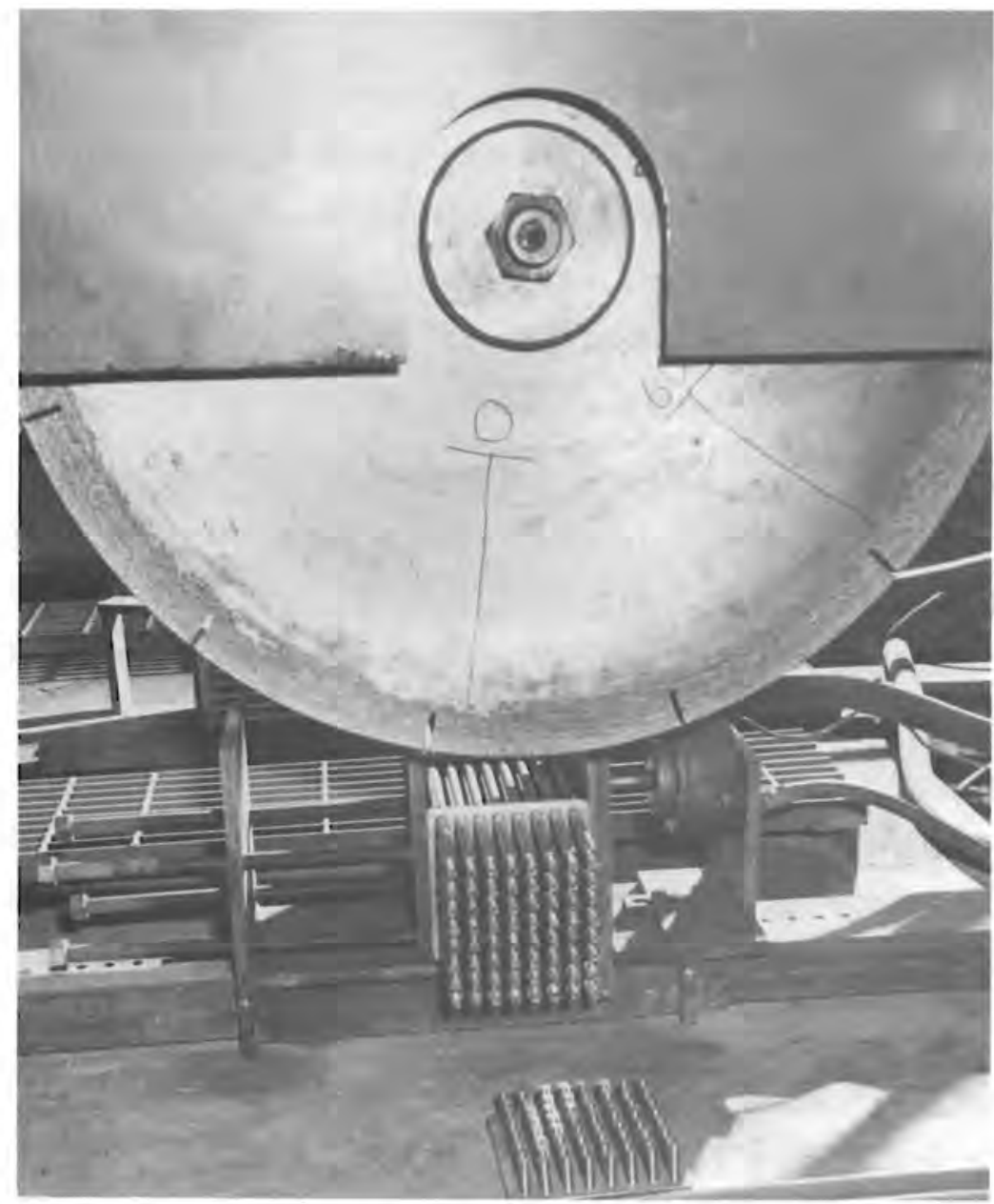

FIGURE 4. Simulated BWR Fuel Bundles with Springs Shown as Cut on the PNL Arc Saw

$\operatorname{arc}$ saw at arc currents ranging from 1200 to $2000 \mathrm{~A}$. The detailed cutting data are shown in Appendix B. The detritus was potted in cement and polished to exhibit the cross section in the micrographs. The particle size is estimated from the micrographs to be a uniformly distributed $-18,+32$ mesh. The effect on the characteristics of the detritus of varying the cutting parameters (voltage, current, blade speed) was not determined, but it is believed that there will be a significant effect on the particle size and degree of oxidation.

The detritus was subjected to one experimental analysis, which is reported in Appendix $C$. This analysis indicated that the detritus contained $70 \%$ zirconium metal and $30 \% \mathrm{ZrO}_{2}$. As part of this analysis, a sample was ground in a 


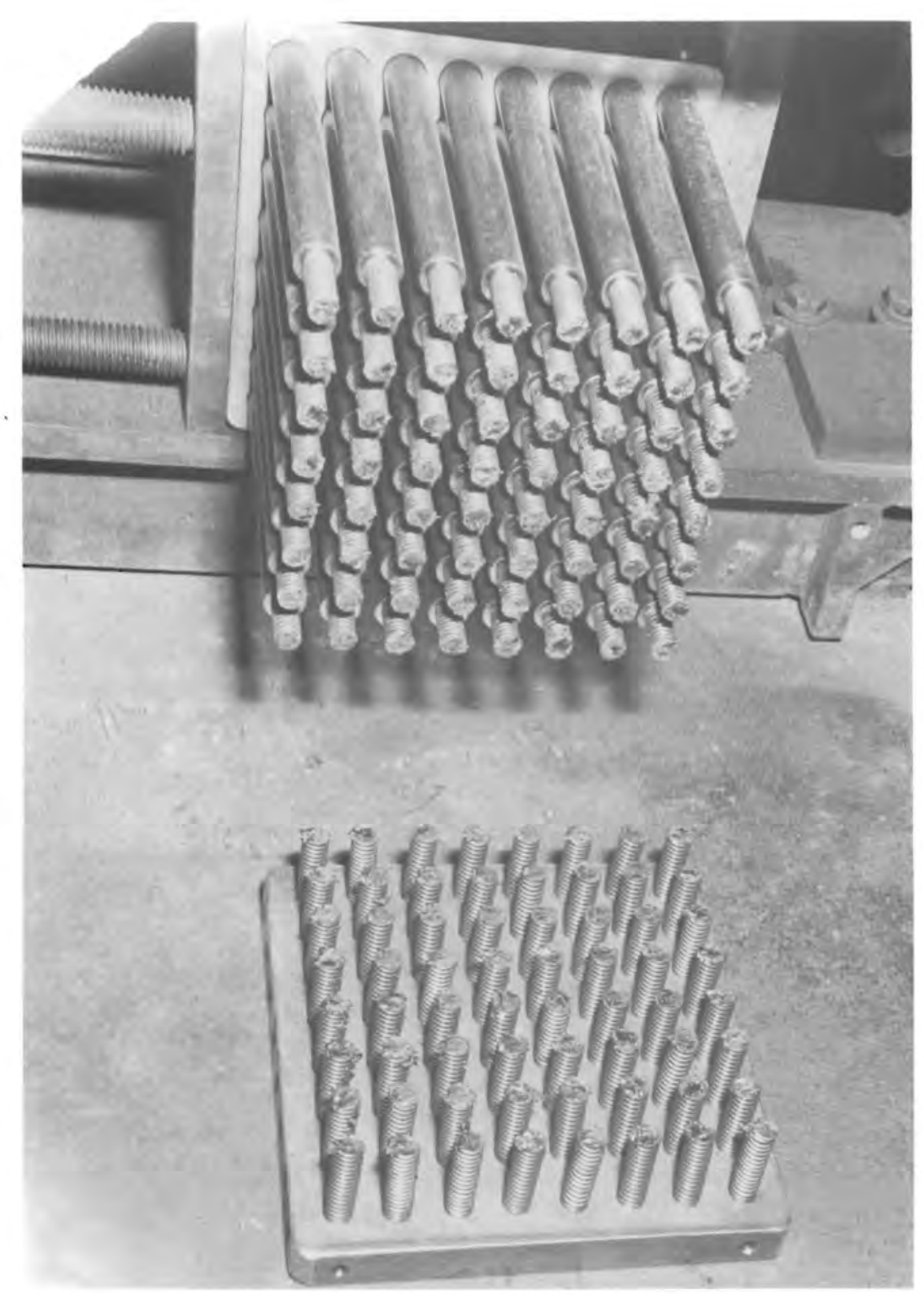

FIGURE 5. Enlarged View of Figure 4

mortar and pestle to 50 mesh, then heated in air to $300^{\circ} \mathrm{C}$ for 2 hours. The furnace temperature was increased, and the sample ignited before the furnace reached $400^{\circ} \mathrm{C}$. The burning was not explosive. The experiment has not been repeated with unground detritus with its characteristic oxide coating intact, which should be much more resistant to ignition in air. 

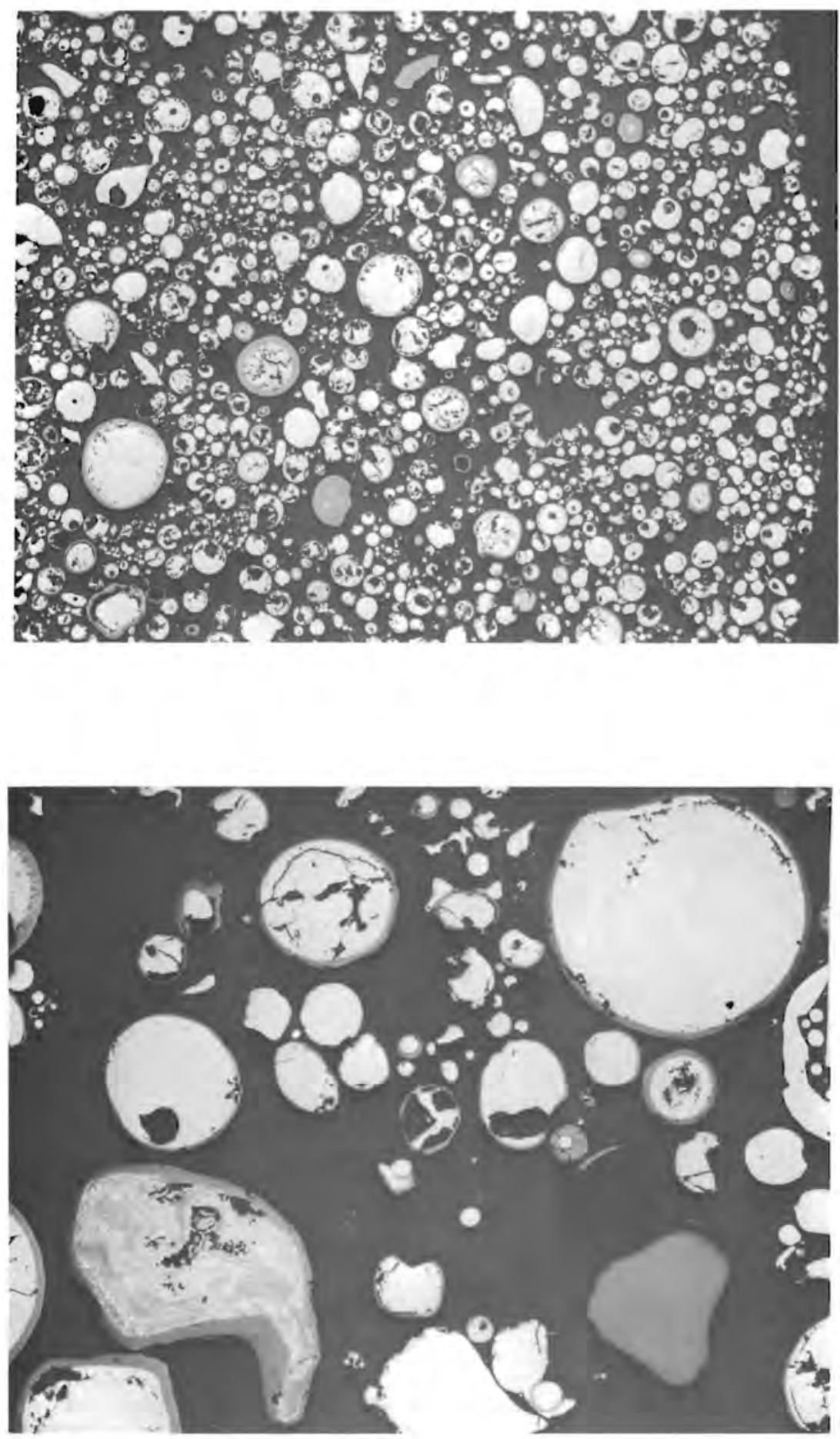

FIGURE 6. Detritus from Cutting Zircaloy with an Arc Saw at 2000 A 

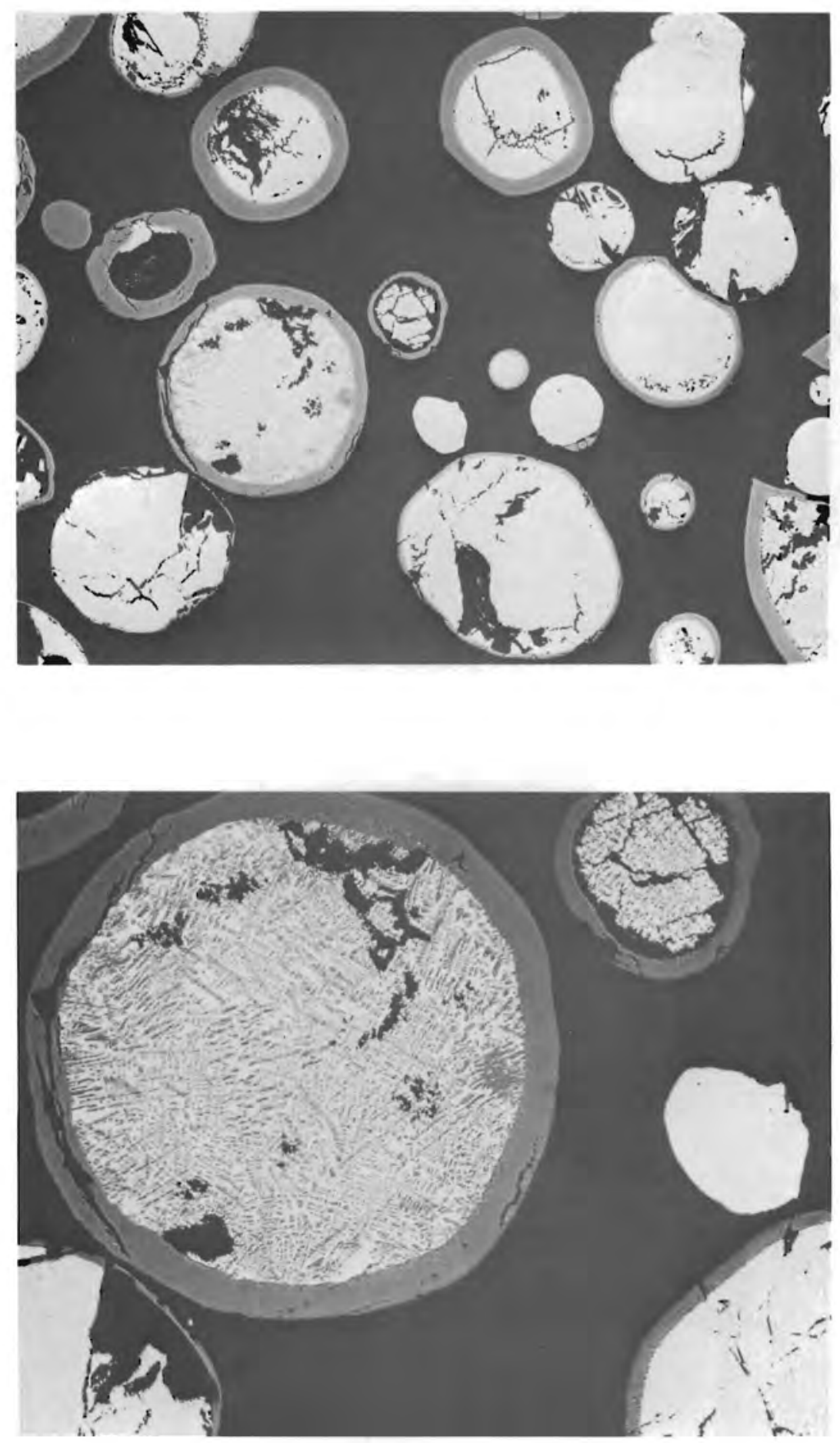

FIGURE 7. Detritus from Cutting Zircaloy with an Arc Saw at $2000 \mathrm{~A}$ 


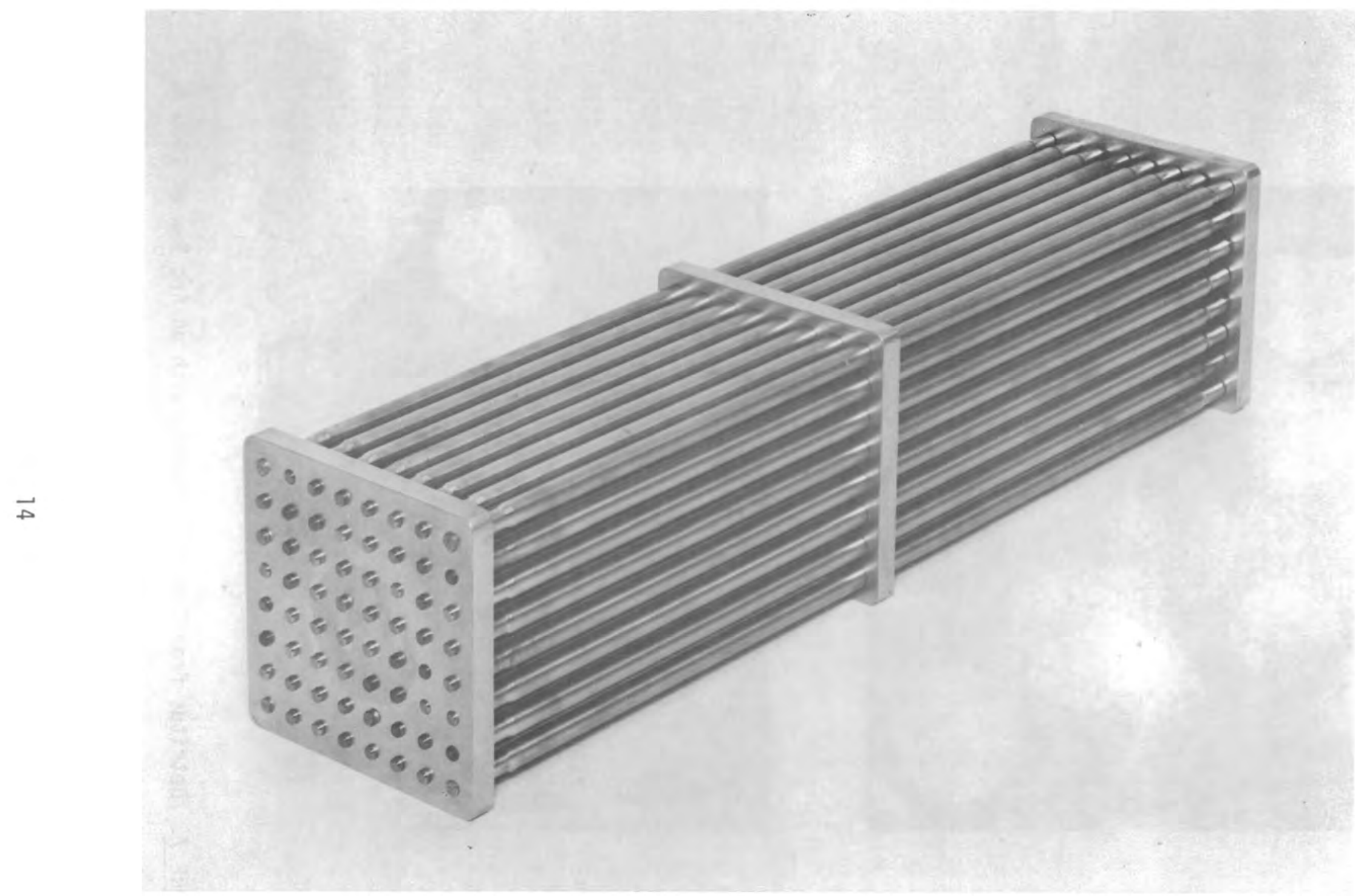

FIGURE 8. Dummy Bundle Made Up of Zircaloy Tubes Plugged with Zircaloy End Caps Held by 304 SS Spacers 


\section{CONCLUSIONS AND RECOMMENDATIONS}

The following conclusions and recommendations are based upon the work covered by this report, which comprises three phases:

- study of existing LWR fuel reprocessing technology and installations

- cutting trials of dummy fuel bundles on the manufacturer's arc saw

- design, manufacture, installation, and startup of a cropping development arc saw facility.

\section{CONCLUSIONS}

1. It is desirable to remove the end fittings (cropping) from spent LWR fuel bundles prior to subsequent processing in order to minimize the amount of bulk handled by the system and reduce the volume of TRU waste to be stored/disposed.

2. The arc saw is a good means of cropping spent fuel bundles.

3. The arc saw is admirably suited to remote operation and maintenance.

4. The arc saw cuts under water, which enhances the ability to control and collect the detritus generated by the cropping operation.

5. The detritus from the arc saw, judging from the preliminary testing reported herein, probably presents no severe pyrophoricity or handling risk.

6. The arc saw blade appears to have acceptable life in this type of service.

\section{RECOMMENDATIONS}

1. Complete the arc saw cropping development to optimize fixturing, cutting parameters, and detritus collection and handling methods.

2. Develop the arc saw as a tool in a fuel bundle disassembly technique. 


\section{REFERENCES}

Weihermiller, W. B. 1978. Prototype Arc Saw Cutting Demonstrations.

PNL-2080-13, Pacific Northwest Laboratory, Rich1and, WA 99352. 

APPENDIX A

SPECIF ICATION 49625

DC POWER SUPPLY FOR ELECTRIC ARC SAW 
APPENDIX A

SPECIFICATION 49625--DC POWER SUPPLY FOR ELECTRIC ARC SAW

\section{GENERAL SPECIFICATIONS}

The dc power supply shall be a specially designed dc rectifier for application on an electric arc saw. The 3000-A power supply shall be a continuous rated unit at a load voltage of $40 \mathrm{Vdc}$. This unit shall be secondary thyristor controlled from a double $Y$ with interphase transformer combination.

The unit will be combination air and water cooled in a free-standing steel enclosure. The dc output shall have constant-current and constant-voltage control modes with automatic crossover to either mode from set-point potentiometers for voltage and/or current. Open circuit voltage on the output shall be 60 Vdc during constant current mode, and 40 Vdc by means of voltage limiting during constant voltage mode.

The unit shall be designed to withstand frequent sustained short circuits up to two seconds on the dc output. In addition, the SCR triggering circuit must operate in the presence of up to $20 \%$ harmonic distortion and multiple zero crossings ( 1 to 30 per cycle at $60 \mathrm{~Hz}$ ). The response time of the output and regulator control system shall respond within the time constant of the filter choke to maintain stable operation.

Power factor correction capacitors shall be included sufficient to obtain $0.90 \mathrm{PF}$ at rated output.

PRIMARY INPUT AND CONTROL

Primary control at $480 \mathrm{~V}, 3$-phase, $60 \mathrm{~Hz}$ shall consist of an electrically operated 3-pole molded case circuit breaker (magnetic trip only) for remote on/off control and rated for load amperage. It shall be of American manufacture. Overload protection shall be dash-pot overload relays. A phase loss protection relay shall be furnished. 


\section{TRANSFORMER}

The rectifier transformer shall use $\mathrm{Class} F$ insulation for $110^{\circ} \mathrm{C}$ rise and shall be a forced air-cooled, dry-type, indoor unit. The primary shall be $480 \mathrm{~V}, 3$-phase, $60 \mathrm{~Hz}$ with a double $Y$ with interphase transformer.

Transformer primary shall have four (4) full capacity taps, two (2) FCAN and two (2) FCBN at 2-1/2\% and shall be brought out through stub taps, complete with bolted flexible links for no-load tap changing made accessible through the enclosure door of the transformer section. Transformer shall have three (3) temperature detectors (thermostats inserted in the low-voltage windings) for overtemperature alarm. The unit shall be double-dipped, double-baked, vacuum impregnated, and built with grain-oriented cores to ensure long life, high power factor, and optimum efficiency.

\section{RECTIFIER SECTION}

The water-cooled rectifier section shall consist of six (6) single-wave silicon-controlled rectifier (SCR) arms on the output of the isolation transformer. The SCRs shall have an optimum mean-time-to-failure rating for the proposed service described in the General Specification section of this specification. Minimum peak reverse voltage (PRV) shall be $600 \mathrm{~V}$ PRV for each SCR. SCRs shall be provided with the following:

- DV/DT network

- current limiting fuses

- trigger fuses for fuse failure lockout

- water cooling requirement 6 to $9 \mathrm{GPM}$ maximum $35^{\circ} \mathrm{C}$ water.

DC OUTPUT

The output characteristics shall be as shown on the attached graph, Figure A.1. Load voltage at $3000 \mathrm{~A}$ rated current for each unit shall be $40 \mathrm{Vdc}$. The open-circuit voltages shall be $60 \mathrm{Vdc}$ during constant-current mode and $40 \mathrm{Vdc}$ during constant-voltage mode. A water-cooled smoothing reactor shall be furnished on each unit to limit output ripple to $5 \%$ at rated load voltage. A dc measuring device shall be installed within the power supply enclosure for output metering service and load indication. 


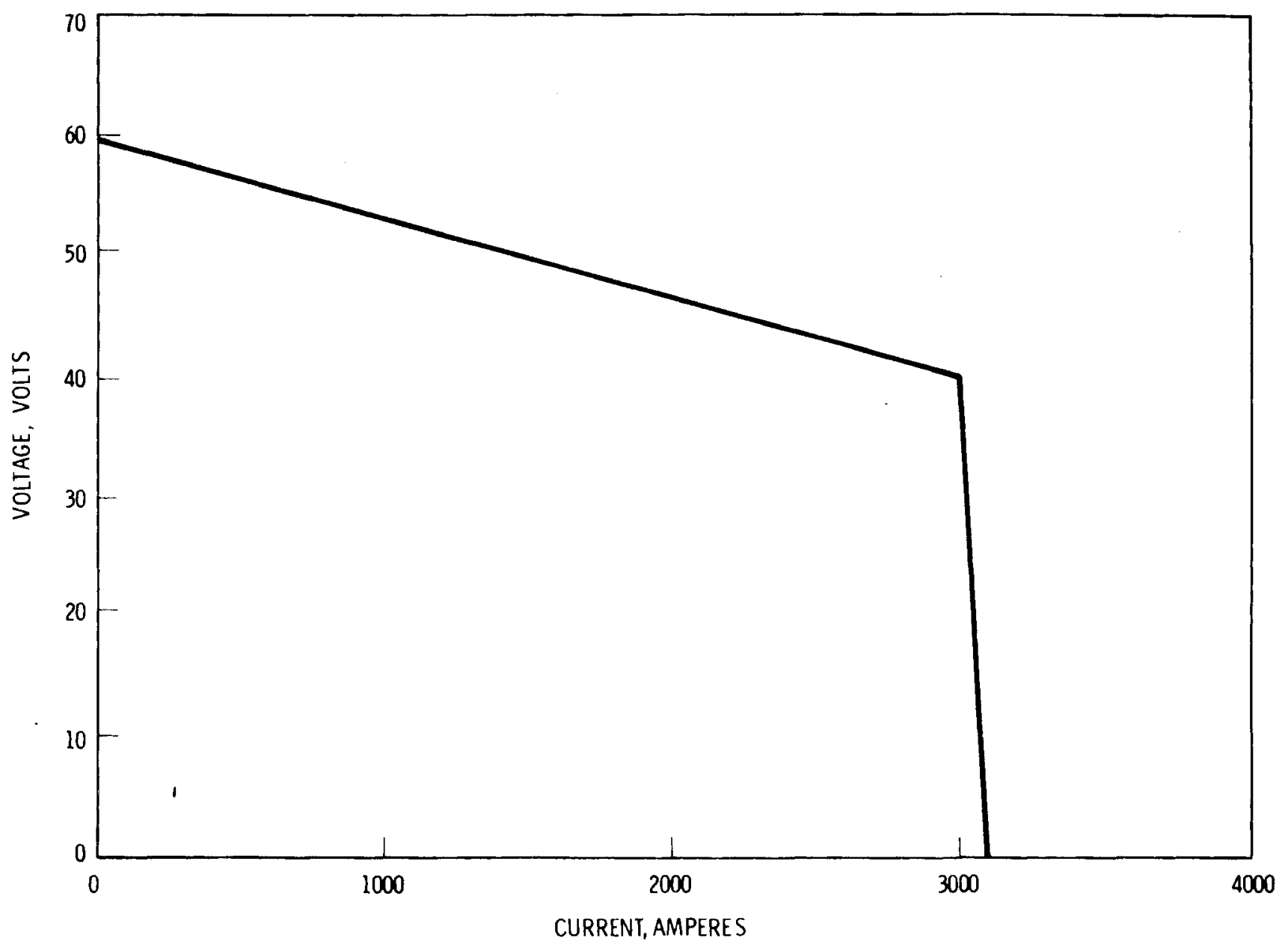

FIGURE A.1. Arc Saw Power Supply Voltage-Current Characteristics

\section{PROTECTIVE FEATURES}

Interlocking shall be provided to cause automatic tripping or al arm indication if the following conditions exist:

1. rectifier transformer overtemperature (warning)

2. water flow loss and/or loss of cooling air (trip)

3. rectifier overtemperature (warning)

4. cooling air overtemperature (warning)

5. excessive line current (overload)

6. blown SCR fuse

7. door interlock. 
In addition, light indications shall be furnished for the following:

1. power on

2. transformer overtemperature

3. SCR overtemperature

4. blown SCR fuse

5. loss of cooling air flow

6. loss of water flow

7. overload condition.

The rectifier enclosure door near the control section shall have the above indicating lights plus the necessary dc voltmeter and dc ammeter.

\section{CONSTRUCTION}

The dc power supply shall be a compact heavy-duty power supply with frametype construction that uses I-beam support that provides for weight distribution. The unit shall be metal enclosed and sectionalized with access doors front and rear. For safety and convenience, the various sections, i.e., high voltage, rectifier section, and control, shall be physically isolated from one another. All insulating components shall be polyester glass, providing minimum moisture absorption and high cracking resistance. All component parts shall be readily accessible for inspection and maintenance while maintaining the smallest dimensions to limit space requirements.

\section{APPLICABLE STANDARDS}

Equipment shall be manufactured to conform to the latest editions of the applicable publications of the organizations listed as follows: ANSI, ASTM, IEEE, and NEMA. In addition, equipment shall strictly be in conformance with the provisions of the National Electrical Code (NFPA 70-1975).

\section{FACTORY TESTS}

The dc power supply shall be factory tested under dummy load at simulated full load and at short circuit condition at rated output amperes, to assure conformance to specification and to check out all control and interconnecting wiring for faster field start-up. 


\section{DRAWINGS}

A complete set of installation drawings, wiring diagrams, operating and service instructions shall be provided with the power supply. In addition, all drawings for approval and review shall be submitted during the manufacturing phase of this contract, as required. 


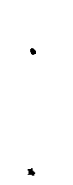


APPENDIX B

SUMMARY OF ARC SAW TESTS 


\section{SUMMARY OF ARC SAW TESTS}

\begin{tabular}{|c|c|c|c|c|c|c|}
\hline $\begin{array}{l}\text { Cut } \\
\text { No. }\end{array}$ & $\begin{array}{c}\text { Voltage, } \\
V\end{array}$ & $\begin{array}{c}\text { Current, } \\
\mathrm{KA}\end{array}$ & $\begin{array}{l}\text { Velocity, } \\
\text { in./min }\end{array}$ & $\begin{array}{c}\text { Blade } \\
\text { Wear, in. }\end{array}$ & $\begin{array}{l}\text { Weight } \\
\text { Loss, g }\end{array}$ & Remarks \\
\hline 1 & 22 & 1.2 & 34 & 0 & 6.5 & Cut tube assembly in half \\
\hline 2 & 22 & 2 & 29 & 0.0005 & 58.5 & Cut through the end pins \\
\hline 3 & 22 & 1.4 & 20 & 0.0024 & 52.5 & Cut through the end pins \\
\hline 4 & 20 & 1.4 & 32 & 0.0007 & -- & $\begin{array}{l}\text { Cut through tubes held } \\
\text { with hose clamps in half }\end{array}$ \\
\hline 5 & 20 & 1.7 & 17 & 0.0029 & 64 & Cut through the end pins \\
\hline 6 & 24 & 1.7 & 21 & 0.0019 & 51 & Cut through the end pins \\
\hline 7 & 30 & 2.6 & 37 & 0.0105 & -- & $\begin{array}{l}\text { Bolted the two stainless } \\
\text { steel end plates and the } \\
\text { spacer together. Cut } \\
\text { this assembly in half }\end{array}$ \\
\hline 8 & 30 & 2.6 & 40 & 0.0124 & -- & $\begin{array}{l}\text { Cut one half section } \\
\text { into quarters }\end{array}$ \\
\hline 9 & 30 & 2.6 & 41 & 0.0057 & -- & $\begin{array}{l}\text { Cut other half section } \\
\text { into quarters }\end{array}$ \\
\hline
\end{tabular}


APPENDIX C

ANALYSIS OF THE SLAG AND SLUDGE SAMPLES

GENERATED FROM THE ARC CUTTING SAW 
APPENDIX C

Date Nov 30, 1976

To G. S. Allison

from F. T. Hara FTH

Subject Analysis of the Slag and Blidge Samples Generated from the Arc Cutting Saw

Your sludge and slag samoles from the arc cutiing sav were analysed to determine the presence of zirconium metal. The X-ray diffraction pattern of both samples were identified as $\alpha-2 \mathrm{r}$ and $\mathrm{ZrO}_{2}$.

Since the $X$-ray diffraction pettern show:d zirconium metal, the metal content in the samples were deternined by igniting a weighed sample in the mufle furnace. The sarples were ground to less than 50 mesh and heated to $300^{\circ} \mathrm{C}$ for about 2 hours. When the muf le temperature was increased to $400^{\circ} \mathrm{C}$, both the samples ignited and burned before the temperature of the furnace reached $400^{\circ} \mathrm{C}$. After ignition of the samples, the furnace temperature was increased to $1000^{\circ} \mathrm{C}$ and left overnight. The weight gain of the samples was assumed to be from

$$
\mathrm{Zr}+\mathrm{O}_{2} \longrightarrow \mathrm{ZrO}_{2}
$$

Using this assumption, the weight percent zirconium metal in the two samples are

Slag from the end-cap = $80 \%$

sludge from the arc saw $=69 \%$

The samples of the sludise and slaz were both readily fround in a metal mortor and pestle to less than 50 mesh. Cne may postulate that zirconiuru hydride caused the brittleness of tie samples. Telephone conversation with Randy Scheele was that zirconium hydrice is pyrophoric, but not as pyrophoric a.s zirconium metal. Thermodynamically, the $\mathrm{ZrO}_{2}$ formation is more stable than the $\mathrm{ZrH}_{2}$ formation. Fandy also stated that $\mathrm{ZrO}_{2}$ will cause zirconium metal to be trittle. Since the difiraction pattern did show $2 \mathrm{rO}_{2}$ and no $\mathrm{ZrH}_{2}$, the brittleness of the samples is probably caused by the oxide in the samples. 
.

.

. 
PNL -3446

UC-85

\section{DISTRIBUTION}

\section{OFFSITE}

A. A. Churm

DOE Chicago Patent Division

9800 South Cass Avenue

Argonne, IL 60439

5 R. P. Whitfield

Spent Fuel Project Office

DOE Savannah River Operations Office

P.0. Box A

Aiken, SC 29801

Acting Director

Fuel Storage and Transfer

Department of Energy

Germantown, MD 20545

27 DOE Technical Information Center

Hubert Baker

Savannah River Plant

E. I. du Pont de Nemours and Company

Aiken, SC 29801

F. D. King

Savannah River Plant

E. I. du Pont de Nemours and Company

Aiken, SC 29801

F. S. Waters

Savannah River Plant

E. I. du Pont de Nemours and Company

Aiken, SC 29801

M. P. McGahee

AFR-SFS Information Service

Savannah River Plant

E. I. du Pont de Nemours and Company

Aiken, SC 29801
OFFSITE

S. W. 0'Rear, TIS

Savannah River Laboratory

E. I. du Pont de Nemours and Company

Aiken, SC 29801

3 J. D. Spencer

Savannah River Laboratory

E. I. du Pont de Nemours and Company

Aiken, SC 29801

ONSITE

DOE Richland Operations office

P. A. Craig

H. E. Ransom

27 Pacific Northwest Laboratory

G. S. Allison (10)

W. F. Bonner

T. D. Chikalla

R. L. Dillon

C. R. Hann

0 . F. Hill

J. H. Jarrett

R. S. Kemper

R. R. King

J. L. McElroy

H. H. Van Tuy 1

Publishing Coordination (2)

Technical Information (5) 


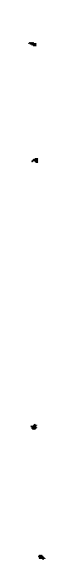

